Editorial

\title{
Editorial to the Issue on Legitimization of Private and Public Regulation: Past and Present
}

\author{
Melanie Coni-Zimmer ${ }^{1}$, Klaus Dieter Wolf ${ }^{1, *}$ and Peter Collin ${ }^{2}$ \\ ${ }^{1}$ Peace Research Institute Frankfurt, 60329 Frankfurt am Main, Germany; E-Mails: zimmer@hsfk.de (M.C.-Z.), \\ kdwolf@t-online.de (K.D.W.) \\ 2 Max Planck Institute for European Legal History, 60323 Frankfurt am Main, Germany; E-Mail: collin@rg.mpg.de \\ * Corresponding author
}

Submitted: 13 February 2017 | Published: 15 March 2017

\begin{abstract}
This thematic issue brings together research from political science and legal history about legitimacy discourses covering different forms of public-private co-regulation and private self-regulation, domestic and transnational, past and present. These forms of governance highlight the important role of non-state actors in exercising public authority. There has been a growing debate about the legitimacy of non-state actors setting and enforcing norms and providing public goods and services. However, the focus of this thematic issue is not on developing abstract criteria of legitimacy. Rather, the authors analyze legitimacy discourses around different cases of privatized or partly privatized forms of governance from the early $20^{\text {th }}$ century until today. Legitimacy is subject to empirical and not normative analysis. Legitimacy discourses are analyzed in order to shed light on the legitimacy conceptions that actors hold, what they consider as legitimate institutions, and based on what criteria. The particular focus of this thematic issue is to examine whether the significance of democratic legitimacy is decreasing as the importance of regulation exercised by private actors is increasing.
\end{abstract}

\section{Keywords}

hybrid regulatory regimes; legal history; legitimacy discourses; patterns of legitimation; public and private regulation; transnational governance

\section{Issue}

This editorial is part of the issue "Legitimization of Private and Public Regulation: Past and Present", edited by Klaus Dieter Wolf (Peace Research Institute Frankfurt, Germany), Peter Collin (Max Planck Institute for European Legal History, Germany) and Melanie Coni-Zimmer (Peace Research Institute Frankfurt, Germany).

(C) 2017 by the authors; licensee Cogitatio (Lisbon, Portugal). This article is licensed under a Creative Commons Attribution 4.0 International License (CC BY).

\section{Non-State Actors and Different Forms of Governance}

In political science, the growing role played by non-state actors in governing domestic affairs has been acknowledged since the 1980s. With regard to transnational regulation, International Relations scholars have analyzed the growing regulatory pluralism mainly since the 1990s when global governance institutions in which non-state actors exercise public authority began to mushroom (Abbott \& Snidal, 2009; Dingwerth \& Pattberg, 2009; Rittberger, Huckel, Rieth, \& Zimmer, 2008). However, political scientists tend to neglect that forms of governance, including non-state actors, are not a recent phenomenon.
Autonomous regulations of merchants that developed since the medieval times (Cutler, 2003), or the activities of chartered companies in foreign territories (Wolf, 2010) are but two examples. Focusing on the domestic context, research from legal history has shown that private and hybrid forms of regulation have existed long before, complementing or even substituting state regulation (Collin, Bender, Ruppert, Seckelmann, \& Stolleis, 2014).

To take as wide account as possible of different kinds of privatized regulatory activities, the contributions to this thematic issue start out from a broad understanding of regulation. From the perspectives of their respective disciplines, the authors address debates about the 
legitimacy of public, private and hybrid norm setting, concretization, implementation, and enforcement, but also of activities regarding the provision of public goods. Different types of regulation are analyzed at the local, regional, national or transnational level. The degree of autonomy that non-state actors enjoy in exercising regulatory functions may be assigned case-by-case to a continuum on which the role of the state is decreasing and the role of non-state actors is increasing (Börzel \& Risse, 2005, p. 201). Forms of governance that can be located along this continuum include the delegation by the state to private actors where the role of the state remains rather strong, different forms of public-private co-regulation where authority is shared between the states and non-state actors, and private self-regulation where non-state actors take center stage. Against the notion that the state has no role in purely private initiatives, we hold the view that there is always some kind of public 'shadowing' because the state or intergovernmental authorities can - at least theoretically-intervene and regulate. In that sense, we understand public authority exercised by private actors as regulated self-regulation (Wolf, 2014) because it takes place under the shadow of hierarchy.

\section{Legitimacy and the Importance of Democratic Standards}

Examining the legitimacy of institutions has become a pertinent topic in legal history, political science and other disciplines. The growing role of public-private and private forms of governance-in the domestic sphere and beyond the nation-state-makes things more complex. ${ }^{1}$ From the perspective of law, attempts to justify the exercise of regulatory authority by non-state actors have always been a great challenge. In political science, normative approaches ${ }^{2}$ prevail in which certain normative standards are developed and/or applied in empirical studies to evaluate the extent to which a given institution meets them. The literature usually distinguishes between input and output legitimacy (Scharpf, 1999). ${ }^{3}$ Input legitimacy refers to procedural standards to secure democratic rights to participation, transparency or accountability. Output legitimacy relates to the effectiveness of regulation, to its responsiveness or reliability or to the achievement of goals in the common interest.

Taking up this distinction between input and output legitimacy, the approach taken by the contributors to this thematic issue is nevertheless different. They analyze in their respective empirical cases which of the above patterns of legitimation are actually used in concrete discourses around current and historical regulatory institutions. The overarching question concerns the role of democratic standards for the legitimation of pri- vate and public-private forms of governance in contrast to output-related criteria. Existing research strands lead to different expectations regarding this issue (see Wolf, 2017, pp. 63-74). On the one hand, the rise of the outputoriented neoliberal, new public management and governance paradigms with their focus on problem solving and the provision of public goods leads to the conjecture that justificatory grounds relating to democratic legitimacy are diminishing in importance vis-à-vis output-centered criteria. Moreover, private actors' epistemic authority, i.e. their acknowledged expertise or moral authority, differs from the political authority attributed to the state and might for that reason alone require different justificatory grounds (see Simmerl \& Zürn, 2016). On the other hand, increasing reference to input-related democratic legitimacy standards could be expected because of the extending quality of public authority exercised by private regulators, including more coercive mechanisms instead of voluntary coordination and a stronger interference with state-based regulation.

\section{Contributions and Results}

The types of privatized forms of governance addressed in this issue cover the period from the early 20th century until today. In the first three contributions, legal historians examine different forms of co-regulation in the domestic sphere in the interwar period. They analyze legitimation discourses in the scholarly literature in Belgium and France (Rudischhauser), Germany (Collin), and Italy (Cau). The next two contributions provide a long-term perspective on self-regulatory initiatives: Casagrande (2017) analyzes the development of social clubs, a form of societal self-regulation, in the province of Buenos Aires, Argentina. Balleisen (2017) examines the development of Better Business Bureaus, a business self-regulation initiative, in the USA. Moving on to the sphere beyond the state, the three following contributions by political scientists focus on contemporary forms of transnational governance. The contribution by Krahmann (2017) looks at two contemporary cases of delegation of authority to private actors as part of the international intervention in Afghanistan. Wolf (2017) examines the public-private co-regulation in the field of sports, and Dingwerth (2017) analyzes privatized forms of governance in the field of sustainability governance.

In an overall assessment of the various findings no single identifiable pattern can be discerned which could provide an easy answer to the overarching question. The significance of criteria for legitimacy varies over time and according to the specific context. Collin (2017) and Rudischhauser (2017) point to the importance of the output dimension for the legitimation of self- and co-regulatory regimes in the interwar period. The protagonists in con-

\footnotetext{
1 See, among others, Brassett and Tsingou (2011), Dingwerth (2007), Bernstein (2011), and Take (2012).

${ }^{2}$ Generally, normative and sociological approaches to the study of legitimacy can be distinguished (see Buchanan \& Keohane, 2006; Peters, 2013; Bernstein, 2011).

${ }^{3}$ See, among others, Buchanan and Keohane (2006), Dingwerth (2007), Flohr, Rieth, Schwindenhammer and Wolf (2010), and Take (2012).
} 
temporary scholarly debates emphasized an improved quality of norms and the superior expertise of non-state actors. Moreover, the contributions highlight that justifying the exercise of authority by private actors was closely intertwined with the perceived crisis of parliamentary systems. In contrast to the three studies on the interwar period, the long-term study of social clubs in Argentina by Casagrande (2017) highlights the use of classic democratic criteria, such as participation, for legitimizing self-regulation. In addition, these four studies, as well as Balleisen's (2017) contribution, demonstrate how deeply intertwined justificatory discourses are with the specific national normative environment to which (new) governance initiatives must be linked. Among the contributions analyzing current cases of transnational governance, Dingwerth (2017) argues that the importance of democratic legitimation narratives has declined over time in the field of sustainability governance. Democratic legitimation was more important in the 1990s when private transnational governance schemes became much more prominent. They became less relevant when privatized governance had become more common and accepted. Democratic criteria are also less important when the 'state prerogative' holds, i.e. when intergovernmental regulation exists. This finding is echoed by Krahmann's study (2017). Foreign interventions in health and security governance in Afghanistan are primarily legitimated with regard to (expected) performance. This might be due to the fact that these non-state interventions are already backed by a strong government, and a net of donors and international organizations, respectively. In addition, her contribution points to potential trade-offs between input and output legitimacy. In his contribution on the sporting world's hybrid regulatory regime, Wolf (2017) concludes that the values used to appraise the statebased components of the regime do not differ systematically from those used to appraise the private elements. Justificatory grounds founded on normative criteria relating to fundamental individual rights and democratic procedure do not appear to be diminishing in importance visà-vis performance-related considerations. A reason for this may indeed be the new quality of public authority exercised by private regulators.

Next to the expected input- and output-related arguments, whose importance varies in the different case studies depending on the context, it might be valuable for future research to put more emphasis on examining criteria that go beyond this dichotomy for legitimating certain forms of governance. Such criteria might be a result of tying justificatory arguments to the specific historical and national contexts. For example, in his study of societal self-regulation in Argentina, Casagrande (2017) highlights the importance of emotional appeals selected to represent the past. Collin's (2017) analysis of corporatist thinking in Germany also hints at the use of such criteria when scholars emphasize a corporative tradition in Germany that is thought to match the national identity. Such unorthodox, unexpected arguments used to legitimize regulatory arrangements can only be identified when using an empirical, bottom-up approach to the analysis of legitimacy discourses, as employed by the contributors to this issue.

Obviously, context is of high significance for the criteria and standards used to legitimize private and publicprivate forms of governance (see also Bernstein, 2011). This holds true for different national contexts, but also for 'world time'. The importance of embedding legitimation discourses in different national contexts is best demonstrated by the three historical contributions on the interwar period: In Germany and Italy with their (almost) uninterrupted tradition of semi-autonomous associations and corporations, the debates showed more openness for corporatist arguments than in France with its 'jacobine' doctrine. The fact that corporatist structures were anchored in the constitutional order of Italy shaped the lines of argumentation in a different way than in Germany, where appropriate regulations only existed in embryonic form (Collin, Cau, Rudischhauser). The study on social clubs also shows impressively how arguments supporting self-regulatory practices are shaped by national history and collective experiences (Casagrande). The importance of world time is underpinned by the two long-term studies on self-regulation (Casagrande and Balleisen) as well as by the study on governance in the field of sustainability (Dingwerth). In particular, Balleisen's study on Better Business Bureaus demonstrates how legitimation discourses can change over time. The study by Dingwerth shows how the development of sustainability governance has changed the legitimation requirements that new institutions face.

The contributions to this issue also highlight the importance of different audiences that may be addressed by and involved in legitimation discourses. These discourses might develop rather independently, or they might be linked and influence each other. Audiences can be located within a single state (see Balleisen's contribution), in different states, or in the domestic and transnational sphere (see Krahmann, 2017). This may lead to contradictions and trade-offs because different audiences can have different expectations with regard to what a legitimate institution should look like. The same argument may, therefore, increase the legitimacy of an institution with one audience and at the same time decrease it with other audiences. For further research, it might be instructive to explore more systematically different audiences of transnational governance institutions in national contexts where heterogeneous expectations might exist.

Finally, the contributions to this issue also provide interesting insights into the role of the state with regard to the emergence of private and public-private forms of governance and their legitimation. Arguments in favor of corporatist systems in the interwar period were closely linked to the limited acceptance of parliamentary systems. A 'perceived crisis of state regulation' (Rudischhauser, 2017, p. 13) was the point of departure 
for arguing for a more important role for non-state actors. Justifications for the latter were related to the delegitimation of parliaments. In a similar vein, the emergence of privatized forms of authority in the transnational sphere can be linked to the failure of the state and intergovernmental institutions to regulate transnational problems. Public regulators are perceived as 'overburdened' (Krahmann, 2017, pp. 54-62) which results in governance gaps that non-state actors seek to fill (Dingwerth, 2017). But the emergence of private regulatory authority is not limited to areas where such governance gaps exist. It can also be employed to support the implementation of state regulation. In particular, the longterm studies by Balleisen (2017) and Casagrande (2017) demonstrate that the role of the state in legitimating selfregulatory arrangements can change over time and that self-regulatory initiatives adapt their strategies as a response to changing capacities of and ideas about the state. The public-private pendulum seems to be swinging over time and will probably do so in the future, influencing how public and private governance contributions are perceived and legitimated.

\section{Acknowledgements}

This publication was supported by the DFG-funded Cluster of Excellence 'Normative Orders' at Goethe University Frankfurt am Main. It draws on papers presented at an international workshop held on April $8^{\text {th }}-9^{\text {th }} 2016$ and organized by the Peace Research Institute Frankfurt, the Max Planck Institute for European Legal History, and the Cluster of Excellence. We are grateful to the contributors for accepting our invitation, to the anonymous reviewers for their valuable suggestions, to the editorial team of Politics and Governance for their efficient support, and to Rodrigo Gomes Quintas da Silva for his encouraging and efficient handling of the entire process.

\section{References}

Abbott, K. W., \& Snidal, D. (2009). The governance triangle: Regulatory standards institutions and the shadow of the state. In W. Mattli \& N. Woods (Eds.), The politics of global regulation (pp. 44-88). Princeton, NJ: Princeton University Press.

Balleisen, E. J. (2017). American Better Business Bureaus, the truth-in-advertising movement, and the complexities of legitimizing business self-regulation over the long term. Politics and Governance, 5(1), 42-53.

Bernstein, S. (2011). Legitimacy in intergovernmental and non-state global governance. Review of International Political Economy, 18(1), 17-51.

Börzel, T., \& Risse, T. (2005). Public-private partnerships: Effective and legitimate tools of international governance? In E. Grande \& L. W. Pauly (Eds.), Complex sovereignty: Reconstituting political authority in the twenty-first century (pp. 195-216). Toronto: University of Toronto Press.
Brassett, J., \& Tsingou, E. (Eds.). (2011). Legitimacy and global governance [Special Issue]. Review of International Political Economy, 18(1).

Buchanan, A., \& Keohane, R. O. (2006). The legitimacy of global governance institutions. Ethics \& International Affairs, 20(4), 405-437.

Casagrande, A. E. (2017). Between history and passion: The legitimacy of social clubs in the Province of Buenos Aires (2001-2007). Politics and Governance, 5(1), 34-41.

Cau, M. (2017). The public-private dichotomy in Fascist corporativism: Discursive strategies and models of legitimization. Politics and Governance, 5(1), 26-33.

Collin, P. (2017). The legitimation of self-regulation and co-regulation in corporatist concepts of legal scholars in the Weimar Republic. Politics and Governance, 5(1), 15-25.

Collin, P., Bender, G., Ruppert, S., Seckelmann, M., \& Stolleis, M. (Eds.). (2014). Regulierte Selbstregulierung in der westlichen Welt des späten 19. und frühen 20. Jahrhunderts. Frankfurt am Main: Klostermann.

Cutler, A. C. (2003). Private power and global authority: Transnational merchant law in the global political economy. Cambridge: Cambridge University Press.

Dingwerth, K. (2007). The new transnationalism: Transnational governance and democratic legitimacy. Houndmills: Palgrave Macmillan.

Dingwerth, K. (2017). Field recognition and the state prerogative: Why democratic legitimation recedes in private transnational sustainability regulation. Politics and Governance, 5(1), 75-84.

Dingwerth, K., \& Pattberg, P. (2009). World politics and organizational fields: The case of transnational sustainability governance. European Journal of International Relations, 15(4), 707-744.

Flohr, A., Rieth, L., Schwindenhammer, S., \& Wolf, K. D. (2010). The role of business in global governance. Houndmills: Palgrave Macmillan.

Krahmann, E. (2017). Legitimizing private actors in global governance: From performance to performativity. Politics and Governance, 5(1), 54-62.

Peters, D. (2013). Rethinking the legitimacy of global governance: On the need for sociological research and philosophical foundations (Global Cooperation Research Papers 2). Retrieved from https:// www.gcr21.org/publications/research-papers

Rittberger, V., Huckel, C., Rieth, L., \& Zimmer, M. (2008). Inclusive global institutions for a global political economy. In V. Rittberger \& M. Nettesheim (Eds.), Authority in the global political economy (pp. 13-54). Houndmills: Palgrave Macmillan.

Rudischhauser, S. (2017). From 8-hour-day to 40-hourweek: Legitimization discourses of labour legislation between the wars in France and Belgium. Politics and Governance, 5(1), 6-14.

Scharpf, F. (1999). Governing in Europe: Effective and democratic? Oxford and New York, NY: Oxford University Press. 
Simmerl, G., \& Zürn, M. (2016). Internationale Autorität. Zeitschrift für Internationale Beziehungen, 23(1), 38-70.

Take, I. (2012). Legitimacy in global governance: International, transnational and private institutions compared. Swiss Political Science Review, 18(2), 220-248.

Wolf, K. D. (2010). Chartered companies: Linking private security governance in early and post modernity. In K. D. Wolf \& N. Deitelhoff (Eds.), Corporate security responsibility? Private governance contributions to peace and security (pp. 154-176). Basingstoke: Palgrave Macmillan.

Wolf, K. D. (2014). The non-existence of private selfregulation in the transnational sphere and its implications for the responsibility to procure legitimacy: The case of the lex sportiva. Global Constitutionalism, 3(3), 275-309.

Wolf, K. D. (2017). Patterns of legitimation in hybrid transnational regimes: The controversy about the lex sportiva. Politics and Governance, 5(1), 63-74.

\section{About the Authors}

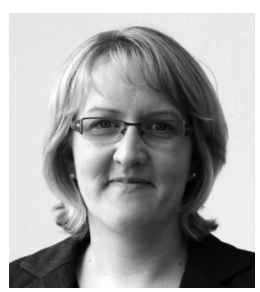

Melanie Coni-Zimmer is a research fellow at the Peace Research Institute Frankfurt, Germany. She holds a doctoral degree in political science from the Technische Universität Darmstadt, Germany. Her areas of research include the role of non-state actors and new forms of governance in international relations. She works on the effects of corporate operations in developing countries and in zones of violent conflict, examining the diffusion and localization of global institutions.

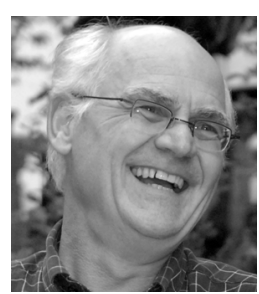

Klaus Dieter Wolf is Professor of International Relations at Technische Universität Darmstadt, Germany, and was formerly Executive Director of the Peace Research Institute Frankfurt. He has written extensively on private actors in global governance and on international institutions. He is one of the Principal Investigators of the Frankfurt Cluster of Excellence 'Normative Orders'. His publications include The Role of Business in Global Governance (Palgrave Macmillan, 2010, co-author), Global Crime Governance (Palgrave Macmillan, 2013, co-editor), and Resistance and Change in World Politics (Palgrave Macmillan, 2017, co-editor).

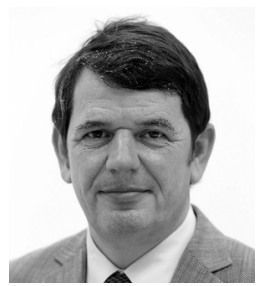

Peter Collin has been working at the Max Planck Institute for European Legal History since 2008. He was DFG Fellow at the Graduate School for European Legal History in Frankfurt am Main from 1994 to 1997 . From 1997 to 1999 he practised law; from 2000 to 2008 he was a research assistant at the University of Greifswald. There he obtained a post-doctoral qualification (Habilitation) in public law, modern legal and administrative history, and science of public administration in 2008. 